\title{
Employment of Unskilled Craft Workers in the UAE Construction Projects: Explicating the Reasons
}

\author{
Mohammed Albattah, Adejumo Saheed, Muhammed Tariq Shafiq
}

\begin{abstract}
The United Arab Emirates construction industry is beset with negative project performance outputs, such as defects, low productivity, delay in completion, and higher costs. Most critical among the recorded reasons for having these undesirable outputs is the engagement of unskilled craft workers. However, the demand for construction projects in the UAE is continually increasing, especially after Dubai won hosting of Expo 2020, as this consequently translates to increased demand for skilled construction craft workers, if optimal project delivery performance must be achieved. Therefore, subject matters related to skillfulness and productivity of construction craft workers become research windows for academic scholars and industry investigators in the UAE built environment. The main purpose of this study is to explicate the reasons behind employment of unskilled craft workers in the construction projects from the management level perspective. To meet this purpose, the authors conducted in-depth interview with construction project managers. The results show number of reasons why unskilled craft workers are been hired and the effect of specialized certificates on hiring the craft workers.
\end{abstract}

Index Terms: craft workers, Dubai construction labour market, hiring, skills, and reasons.

\section{INTRODUCTION}

The construction industry is universally considered to be the live wire of any country. To a very large extent, the evolution of a country and its advancement is generally determined by the superiority of its infrastructure and construction projects. In the United Arab Emirates (UAE), the construction industry plays a major role in national economic growth, it accounts for the employment of approximately 1.2 million workers (20\% of the total workforce) in 2014 only; the highest percentage amongst all other sectors in the UAE. Furthermore, the volume of salaries for construction workers this very year was 50.3 billion Dirhams (12.3\% of the total volume of salaries); the third highest percentage amongst all other sectors, even surpassing "governmental services" and "bulk, retail trade and reparation services" sectors [1]. According to [2], the construction industry accounts for $14 \%$ of the UAE's Gross Domestic Product (GDP). Although, the demand for the construction projects in the UAE is increasing,

Revised Manuscript Received on July 20, 2019.

Mohammed Albattah, Architectural Engineering, United Arab Emirates University, Al Ain, UAE. (e-mail: mohammed.battah@uaeu.ac.ae).

Adejumo Saheed, Projects and Technical Services Department, Westfield Global Construction Ltd, headquartered at Garki District, CBD, Abuja, Nigeria (email: adesahind@gmail.com).

Muhammed Tariq Shafiq, Architectural Engineering, United Arab Emirates University, Al Ain, UAE. (e-mail: muhammed.tariq@uaeu.ac.ae). especially after Dubai won hosting rights for the Expo 2020 [3], translating into increase in demand for the construction workers. Reference [4] explained that investment in infrastructure continues to form a substantial part of the construction and projects sector in the UAE. The data provided by BNC's Construction Analytics confirm this, as 3,200 projects are active in the Dubai's urban construction sector alone, amounting to a combined estimated value of over US $\$ 245$ billion [4].

Workers are the main fuel for successful running of the construction industry, and skilled workers are the heart of construction. Reference [5] posited that construction industry is a labour intensive industry; hence labour productivity remains crucial issue for the profitability of construction projects [6]. Likewise, skilled workers are quintessential for the successful growth of construction industry [7]. In a study conducted by [8], it was realized that one of the major contributors to construction defects in the building sector was unskilled craft workers, owing to their poor level of the skill. Moreover, reference [9] posited that unskilled labour is the main responsible factor for construction delays and cost overrun.

In the UAE, particularly Dubai, reference [10] confirmed that workforce employed in projects is of mixed nationalities, which bring different traditions, rules, habits, and religions. For example, the religious holidays include holy Friday for Muslims, Sunday holiday for Christians, and regular holidays and festivals for Indians. The impact of such a multi-national workforce to construction is significant [10]. Therefore, construction labour market in the UAE has a unique feature of craft workers' national diversity. Craft workers come from different backgrounds in terms of culture, education, and ethnicity [11], [12]. In 2010, foreign workers (non-Emiratis) accounted for about $90 \%$ of the entire UAE workforce [13]. Reference [14] mentioned that there are around 202 nationalities existing in the UAE labour market. The India-UAE corridor could be the second largest in the world, and Indian, Bangladeshi and Pakistani expatriates outnumbered Emirati citizens in 2015. Though, reference [12] opined that multicultural backgrounds and poor job security in the UAE construction labour market are among the factors that contribute to having unskilled craft workers [12].

\section{Published By:}


Yet further research work that will seek to understand the factors and circumstances that lead to continued hiring of unskilled craft workers in the UAE construction industry is important in order to mitigate the short and long-term effects on construction projects.

This research sets to inquire into the current state of craft workforce development in the UAE construction industry. Through this analysis, reasons influencing the unceasing employment of unskilled craft workforce will be identified. Within the UAE, this research was limited to completed and ongoing construction projects in Dubai metropolis only. This research focuses on the construction project managers to give their individual accounts of reasons for continued engagement of unskilled craft workers and the effect of specialized certificates on hiring the craft workers.

\section{LITERATURE REVIEW}

The construction industry refers to an extremely diverse sector which consists mainly of craft, professional and industrial services concerning the building, demolition, renovation and maintenance of the built environment. In many locales, construction markets tend to be divided into three broad sub-sectors: civil construction (e.g., roads, highways, water treatment plants, bridges etc.), industrial construction (e.g., oil \& gas platforms and mining infrastructure) and residential and commercial construction (e.g., single-family dwellings, office buildings, condominium developments etc.). Occupationally, the sector includes array of skill and job categories, professionals, managers, for technical and manual jobs; ranging from Architects, Engineers and Project man-agers, to Carpenters, Electricians, Steel fixers and general labour workers [15].

According to the International Standard Classification of Occupations, a job is defined as "a set of tasks and duties performed, or meant to be performed, by one person, including for an employer or in self-employment". As documented, occupation refers to the kind of work performed in a job. The concept of occupation is defined as a "set of jobs whose main tasks and duties are characterized by a high degree of similarity." A person may be associated with an occupation through the main job currently held, a second job, a future job or a job previously held [16].

International Standard Classification of Education (ISCED) states that skill specialization is considered in terms of four concepts: 1) the field of knowledge required; 2) the tools and machinery used; 3 ) the materials worked on or with; 4) the kind of goods and services produced [16]. International Labour Organization's study states that workers are classified into three classes based on the skills and their respective academic standings. There are craft occupations that require skilled labour (high level of trainings), there are those that require semi-skilled labour (low level of trainings), and those occupations that do not require skilled labour (anyone can do the work with some guidance). However, reference [17] states that highly skilled occupations are those requiring specialized education or training which take years to complete (i.e. carpentry, electrification, and pipefitting); and low skilled occupations are those requiring minimal or no training/instruction (i.e. general helping and roofing).
A 2008 survey of establishments indicated that foreign employees made up $89 \%$ of all managers and $99 \%$ of those in unskilled positions. $76 \%$ of foreign workers display a relatively diverse profile in general. As emphasized in the example of Dubai in 2015, 77\% of the "blue-collar" categories (from "craft and related trade workers" to "elementary occupations") employed half of the foreign males and $37 \%$ of females, while $18 \%$ and $14 \%$ more, respectively, were in "trade and services" occupations. On an average, $24 \%$ of Dubai foreign male residents and $40 \%$ of female expatriates were holding managerial and professional positions. Emirati nationals are absent from low-skilled categories, and $11 \%$ of males were employed in the military [10].

\section{A. Why Hiring of Unskilled Craft Workers?}

The lack of job security and poor wages, aging of the work-force, poor image and poor career pathways, among others, dominance of multifaceted cultural background of craft workers play a principal role in hiring of unskilled craft workers. In fact, contractors have lessened training of their craft workers while they heightened hiring of less skilled craftspeople to be competitive in securing jobs [18]. While the UAE's construction industry is almost entirely made up of non-citizens, nearly every foreign worker in the UAE construction sector - from the highest paid Architects, Engineers, Surveyors, and Designers to the lowest paid demolition workers, water carriers, and cleaners - is a migrant on a temporary work visa. UAE citizenship is only very rarely granted to foreigners [15]. Roughly $80 \%$ of the UAE's total population is comprised of migrants, both high and low skilled. In Dubai that figure is close to $90 \%$ [13]. Quickly identifiable problems in the recruitment of unskilled craftspeople include low wages, no clear-cut career path, and a continuing diminishing skilled craftsperson training programme. Low wages is major reason the construction industry is having in retaining skilled labour workers [18], [19]. Thus, recourse is sought to unskilled craft labour.

\section{METHODOLOGY}

The authors conducted in-depth interviews with fifteen construction industry project managers. The questionnaire was prepared using previous studies in the literature review. The authors asked the participants number of questions related to the reasons for hiring unskilled craft workers in the construction industry, and the consideration of the specialized certificates as a factor for hiring the craft workers. These questions include the following:

1) What are the reasons for hiring unskilled craft workers in your company?

2) What are the reasons for having difficulty to find skilled/qualified craft workers in the UAE labour market?

3) What are the common nationalities at the UAE labour market? 
4)Does your company take into consideration the specialized certificate as a factor to hire the craft workers?

Are these specialized certificates a true measure for identifying the craft worker skill's quality? Moreover, can you say that anyone who have a specialized certificate is a skilled worker? 5) Do you provide training to the unskilled craft workers? Is it formal or non-formal training?

\section{RESULTS AND DISCUSSIONS}

There are two main parts in this section, which present the reasons for hiring unskilled craft workers in the construction projects, and the consideration of the specialized certificates as a factor to hire the craft workers.

\section{A. Reasons for hiring unskilled craft workers in the Construction Projects}

The participants' revealed number of reasons for hiring unskilled craft workers in the UAE, Table 1. Most of the participants agree that one of the main reasons was the shortage of skilled workers against the high demand, and the contractors need to hire those available to meet project deadlines. Further, one of the participants said "Majority of the contractors in Dubai result to sub-contractors and recruit the tradesmen with basic skills and education. Once a project is completed, no contractors could maintain their labour force as they cannot bear huge cost of running salary while anticipating new job awards. When they are awarded a new job (especially Dubai Clients want their projects completed in an unreasonable period), they need to go out and find suitable agencies to supply men in order to keep their commitment to the client. When the demands increase for the labour supply agencies, the quality becomes poor." Other reason was that some types of tasks require unskilled workers. Moreover, unskilled workers are cheaper that skilled workers who demand for high salary to accept offer. Therefore, to balance the project cost, some contractors mixed skilled and unskilled workers. In addition, there are no formal trainings or vocational schools in the UAE, while formal training is too costly for companies to afford.

Table 1: Ranking the reasons for hiring unskilled craft workers

\begin{tabular}{lc}
\hline \hline Reasons & No. of Participants \\
\hline Shortage of skilled workers \& Poor labour supply & 7 \\
Saving money (they are cheaper) & 6 \\
Some work require unskilled workers & 4 \\
The owner requires faster project completion & 1 \\
\hline \hline
\end{tabular}

All the participants agreed that majority of the craft workers in the UAE came from India, Pakistan and Bangladesh. According to one of the participants, when workers come to the UAE, they are most likely unskilled, but only learn on the job site to become skilled. However, some of them are hardly acquire the skills owing to communication challenges resulting from language barriers and low education background. Moreover, recruiting companies are not very honest in qualifying foreign applicants for job contracts in the UAE; in some cases workers who are willing to come to the UAE pay the recruiting companies more commissions and kickbacks amounting to chunk (over 50\%) of their projected wages out of desperate desire to secure job within the UAE construction market.

\section{B. Consideration of the specialized certificates as a factor to hire the craft workers}

According to the participants, some companies take into consideration the specialized certificates as a minimum requirement for hiring, at least for some trades. However, all of the participants agreed that specialized certificates are not usually a true measure for the workers' quality and experience as it always concentrates on theoretical part than the practical. In fact, most of the companies consider the workers based on their capability and experience that they will be tested before recruiting. Therefore, site performance is more dominant in determining a worker's skill more than a certificate.

Certificates are required in some crafts because they need highly skilled and knowledgeable workers to do the sensitive work perfectly. However, some workers come with a specialized certificate, but cannot practically showcase what the certificate portrays. One of the participants said "we have seen workers with specialized certificate not performing in their trade. There are many institutions that train workers in crash and crude course and issue certificates within few weeks. Consequentially, these certificates are valueless." Another participant sees value in some workers who have the specialized certificate, even if he/she did not have the required quality or skill. He said "... because the person will be open minded and able to learn faster." Further, some participants mentioned that they consider specialized certificates, but from numbered authorized agencies. One of them said "It depends from where the certificate is issued. For example, in India, the Industrial training institute (ITI) issues certificate after two years of full time course on each trade. Another agency, which we consider from, is Scientific and Technical Center for Building (CSTB) from UK ... we wouldn't consider certificates from any unauthorized agency." Therefore, if the workers have certificates from authorized agencies, construction companies get more productive work with a good quality, in addition to the safety in the jobsite.

To overcome the specialized certificates issue, most of the construction companies send their representative to test and then recruit the workers, because at the end the performance of the skilled worker will be the measure for keeping or terminating him/her. If any worker found not suitable or not doing the job as required, the worker will be treated as helper and will be paid a helper salary, or will be terminated and sent back to his/her country. On the other hand, most of workers are depending on their foremen as they follow his/her instructions. Therefore, construction companies require the Forman and the general Forman to be sufficient and qualified, and to have the needed certificate.

Some companies provide a formal training to the workers after hiring them, either if they have specialized certificate or not. 
One of the participants said "Generally, specialize workers are skilled workers, However we trained them internally or externally as per our requirement as well." Another participant said "... So we provide formal training in our training center located at Jabal Ali for both skilled and unskilled workers." However, not all the companies train their workers because it is require effort, time, and money that the companies are trying to avoid. One of the participants said "It reduces your time and money to train your workers to carry out their works."

\section{CONCLUSION}

Unarguably, skilled labour shortage is one of the challenges assailing the UAE built environment. Both clients and the contractors are therefore enjoined to work together to address this menace. One of the methods to accomplish this is to minimize the use of the low-bid process and move to a system that wills more incentive for contractors to have highly qualified craftspeople. Contractors and owners that find a way to attract and retain quality craftspeople will be considered to be the successful companies of the future. Construction companies should also entrench the culture of routine capacity development, and skill acquisition training for their craft workers. Innovative retention and rewards strategies geared towards endearing, and retaining the few skilled craft workers need to be formulated. To ameliorate the adverse effects of multi-national workers hired to perform same trade, identified skilled workers can be paired with those of similar background who need hands-on training to upgrade their skillfulness.

Lastly, government and concerned organized private sectors are to ensure reliable data and regular record update of supply and demand of the UAE craft workforce. They need to expand provisions for funding for craft workers internship, mentoring, skills development and welfares.

\section{REFERENCES}

1. UAE Government. (2016). Annual Economic Report 2016: 24th Edition.

2. Ali, M. and S. B. (2015). The Applicability Of Just-In-Time In United Arab Emirates Construction Projects College of Engineering, American University of Sharjah 6(2), 120-128.

3. Mehran, D. (2016). Exploring the Adoption of BIM in the UAE Construction Industry for AEC Firms. Procedia Engineering, 145, 1110-1118. https://doi.org/10.1016/j.proeng.2016.04.144

4. Mackenzie, A., Prestige, G., Kotb, S., Mechantaf, K., and Roberts, N. (2019). Construction and projects in United Arab Emirates: overview. Retrieved from https://globalarbitrationnews.com/construction-and-projects-in-united -arab-emirates-overview/

5. Yi, W., \& Chan, A. P. C. (2014). Critical Review of Labour Productivity Research in Construction Journals. Journal of Management in Engineering, 30(2), 214-225. https://doi.org/10.1061/(ASCE)ME.1943-5479.0000194

6. Liu, H., Yu, Z., Zha, H., Zou, Y., \& Zhang, L. (2009). Robust human tracking based on multi-cue integration and mean-shift. Pattern $\begin{array}{lll}\text { Recognition } \quad \text { Letters, } & \text { 827-83), }\end{array}$ https://doi.org/10.1016/j.proeng.2016.11.588

7. Ahmed, S., Houqe, I., \& Sobuz, H. R. (2017). Analysis of Skilled Worker Criteria of Construction Industry. Journal of System and Management Sciences. 7(2), 53-78.

8. Aljassmi, H. A., \& Han, S. (2014). Classification and Occurrence of Defective Acts in Residential Construction Projects. Journal of Civil Engineering and Management, 20(2), 175-185. https://doi.org/10.3846/13923730.2013.801885
9. Yaw, F., Jacob, O., \& Lynn, C. (2003). Causes of Delay and Cost Overruns in Construction of Groundwater Projects in a Developing Countries; Ghana As a Case Study. International Journal of Project Management, 21(5), https://doi.org/10.1016/S0263-7863(02)00055-8

10. Ren, Z., Atout, M., \& Jones, J. (2008). Root causes of construction project delays in Dubai. 24th Annual ARCOM Conference, 1-3 September 2008, Cardiff, UK, Association of Researchers in Construction Management, (September), 749-757.

11. Ailabouni, N., Gidado, K., \& Painting, N. (2007). Factors affecting employee productivity in the UAE construction industry. In Proceeding Conference for Postgraduate Researchers of the Built and Natural Environment (PRoBE), (pp. 33-46).

12. Lohiya, G. (2012). Team building in project management practice in the UAE construction industry. International Proceedings of Economics Development \& Research, 43, 31-35.

13. De Bel-Air, Françoise. "A Note on Syrian Refugees in the Gulf: Attempting to Assess Data and Policies." Explanatory Note No. 11/2015, GLMM, http://gulfmigration. eu. (2018). Demography, Migration, and the Labour Market in the UAE Gulf Labour Markets and Migration. GIGA Focus, (7), 1-24 https://doi.org/10.1038/ncomms13396

14. 202 nationalities in labour market - Khaleej Times. (2016). https://www.khaleejtimes.com/article/20060825/ARTICLE/30825995 2/1002

15. Sertyesilisik, B. (2016). Embending sustainability dynamics in the lean construction supply chain management. YBL Journal of Built Environment, 4(1), 60-78

16. Classification of Occupations. (2012). International Labour Organization, I, 1-420.

17. Vereen, S. C. (2013). Forecasting Skilled Labour Demand in the US Construction Industry. A dissertation submitted to the Graduate Faculty of North Carolina State University.

18. Makhene, D., \& Thwala, W. D. (2009). Skilled labour shortages in construction contractors: A literature review.

19. Albattah, M., Shan, Y., Goodrum, P. M., \& Taylor, T. R. (2016) Relationships between cycles of economic expansion in construction and craft workers' job satisfaction and preferences. Canadian Journal of Civil Engineering, 44(1), 29-36.

\section{AUTHORS PROFILE}

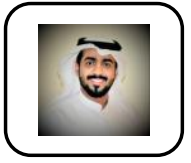

Mohammed Albattah received his Doctoral (Ph.D.) degree in the Construction Engineering and Management program, in the Department of Civil, Environmental, and Architectural Engineering from the University of Colorado Boulder in the United States. His primary research interest is in exploring, analyzing, and developing methods for improving and solving the issues in the construction labor market, focusing on craft workers, and he has number of publications in this area. In 2011, Dr. Al Battah received his Master's degree in Engineering with a concentration in Construction Management from Vanderbilt University in the United States, and in 2007, he received his bachelor's degree in Architecture from Imam Abdulrahman Bin Faisal University in Saudi Arabia.

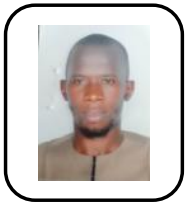

Adejumo Saheed received Bachelor and Master Degrees in Architecture from the Federal University of Technology, Akure, Nigeria. Saheed is registered with dual Nigerian regulatory councils of Architectural Practice (ARCON \& NIA) and American Institute of Architects. He has co-authored publications on Building Information Modelling (BIM) and attended international conferences and workshops on his research interests cutting across BIM, and emerging Technologies for Sustainable Project Delivery. He is presently the Executive Director; department of Projects and Technical Services at Westfield Global Constructing Limited headquartered in Abuja, Nigeria. 
Muhammad Tariq Shafiq has extensive research \& industry experience in enabling organizations for collaborative working using latest digital technologies and processes. He has MSc in Project Management in Construction from University of Salford, UK, and a PhD in Building Information Modelling (BIM) from Northumrbia University at Newcastle upon Tyne, UK. He has played an instrumental role in establishing BIM Academy in the UK, and has contributed to a number of $R \& D$ project funded by UK Government. He has industry consultancy experience in Pakistan, UK, UAE \& Saudi Arabia 